\title{
IFNA13 Gene
}

National Cancer Institute

\section{Source}

National Cancer Institute. IFNA13 Gene. NCI Thesaurus. Code C24481.

This gene plays a role in signal transduction and is involved in the immune response. 